\title{
Influence of Religiopoliticology and Duressed Womankind: Perspective Bangladesh
}

\author{
Md. Kohinoor Hossain \\ PhD Fellow \\ Dept. of Islamic History \& Culture \\ Islamic University, Kushtia \\ Bangladesh \\ Cell Phone: +8801846789678 \\ Email: ap.m.k.hossain@gmail.com
}

Received: December 5, 2018 Accepted: December 8, 2018 Online Published: December 17, 2018

\begin{abstract}
The world is continuing at its own orbiting and fugitive for the adamboma or bomb of Adam in the womankind and mankind, who are classified into the four generations, and they are religious world, nonreligious world, scientist world and humanitarian world but the people of Bangladesh are in the same kind like the world people to find out God and how they use religions, which is that have discussed by this paper. Bangladesh is a land of ice-aged. It has ancient beliefs, fear, and faiths, which are convinced on the inter-ward eyes, concise and understanding. The original people of her are Non-Aryan. Aryans come to here from the Persian and Middle East countries in the caravan of the rules of the chronology, many foreigners who come to Bengal, they are Greeks, Europeans, and Africans, all of them capture Bengali and they rule Bengal. They snatch away their own land, language, culture, economics, politics, beliefs, and love-nets. Here makes up all official religions, someone is downtrodden by them who remake apartheid in the society of Bengal, this is why they are de-throne from their own land, and they try to live as a freedom where they make up folk-religions. Bengalees learn the foreigners' religions and they convert into these official religions. The rulers of Bengal rule them as following the religious doctrines only for getting votes when they need to play political power playing and that is why they use them. They use many styles of God theory. The Bengalees, they can how to use the orders of God that will be sought out in this paper. This paper seeks that how the cultic dynamics radicalization runs in Bangladesh and what is the best concept of God in Bangladesh. All people live in equal in the land of God in Bangladesh that empirically applies, for the globe.
\end{abstract}

Keywords: Allah, Theology, Politicology

\section{Introduction}

When Bangladesh accepts scriptural religions, none can answer this question and who come to settle in the Ban, Bans, Bang, Banga, Bangala, Bangalah, Bangala, Subah-i-Bangala, Bengal, East Pakistan and Bangladesh. None can answer the plain truth. All depend on the foreigners who would rule this place. Only Aryan and Muslim highly kept pressure to convert into scriptural religion and they succeed converting into Islam to live in this world and in this regard, researcher seeks the cultic dynamics radicalizations.

1.1 Research Problems

Bangladesh is today at the facing-confront of religious extremists. Womankind does not get full assurance their freedom empowerment. All want to establish the entities of God. How they all want to use God by leading and ruling the state power? This paper tries discovering the novel theory of God in Bangladesh. 


\subsection{Aims and Objectives}

The researcher has a differentiated aims and objectives. At the order of God, all are equal. However, why here creates conflicting, killing, anarchy, injustice, oppressing, inhumanity and cruelty. The women cannot get their all kinds of rights. They have to keep in prison as the name of house as for their husband. These focus on the global people. God, Religions, and Political concepts of Bangladesh, which are, that has submitted to develop Bangladesh. This paper mentions the plain truth.

\subsection{Research Methodology}

The researcher desires that all religions in the earth are humanitarian but why all are conflicting against other religious actors. Today total Europe, Middle East, America and South Asia are affected by the religious conflicting. In this regard, the author prefers descriptive and hypothesis method that will be submitted as for the conference paper and working paper. There he follows the international research accredited style where he will take references and bibliographies. This is why that for this type of article is not available to focus on for the theology portal. Primarily he has been inspired about this title paper. When the world is thinking, busy for inventing the new policy how to remove this fratricidal moment. He selects to discover this article. This paper will not devalue about the men, women, races, institutions and any other religions. This paper has been composed in simple and dynamical English language. It will only rediscover the historical plain truth. It will use a print theory. He tries to remake the data analyzing from the sources. There will be re-focused about the nomenclature of Bangladesh and God-ship. This paper will use as an empirical application for the world nations.

4. Discussion

4.1 Bangladeshlogy

The name of Bangladesh, which is a kind of country when it starts, none can say correctly, undetermined number of foreigners dominates Bangladesh and they all capture this land to all prefer to establish their doctrines, philosophies, cultures, religions, and languages. Bangladesh has no ancient written history, what the foreign scholars and writers have composed. The people of Bangladesh have spent their days with reciting books and papers for thousands years after thousand years. This people awake from playing on bamboo flute, spending days with hookah smoking for six months and for comfortable with relaxing and the rest of the six months spend working to earn foods and money. ${ }^{[1]}$ In the ways they keep in sleeping for years after thousands years with storytelling. The people, who live, lead, dominate, which areas where these are located. How are these areas? About 80,000 square miles broad spreading made by rivers washing silted plain boundaries land, which is Bangla. Its area is on the east side is Tipera and Lussai valley, on the north side is Shilang mountain and Nepal Tarai area; on the west side is Rajmahal and Chotonagpur mountain's high valley and on the south side is the Bay of Bengal. ${ }^{[2]}$ The word 'Bang' nation, which is colonized area, called as 'Banga' country. In addition, considering the nation is 'Bang', perhaps which, is a vast area that identified as 'Bangal'. ${ }^{[3]}$ There is a man whose name is 'Ban or Bans or Bang' and it is before the five thousands and five hundred years ago, who establishes a settling their living -hood. ${ }^{[4]}$ The people and the land from Rajmahal to Aassam, from Nepal to the Bay of Bengal introduce as 'Bangla and Bangali'. This land is in sub-states that are 'Anga, Banga, Pundra, Summah, Rada, Harikel, Samatata and Sankanat. These sub-states are known as 'Bangladesh'. ${ }^{[5]}$ The surge that surrounds on the Bhagirathi and on the Padma and that is why that land is adjacent to the triangle area that creates as Delta or Badwip and finally this area flourishes as the 'Banga' area to 'Bengal'. [6]

The geographers acknowledge it as the geographical area. ${ }^{[7]}$ According to the Thailand mythology: There is name in the sub-state continental India whose name is 'Ban-Lang or Bang-Lang or Lak-Lang' is a valiant hero of Bangalee who descends to the palace of the Thailand. He defeats the king of this land and he captures this land. He rules this country for many days. He provides his country's nomenclature as 'BangLang'. The inhabitants of 'Bang-Lang' are known as 'Ban or Bans or Vans or Bang'. The word 'Ban or Bans or Bang' is a Tibetan language. It means marshy and humid water-land. According to Mahabharat: "There is a king whose name is 'Bang' he rules that country and this country is renamed as 'Bangal'." [8] The primitive Bangal or Bangla reproduces as Banga. According to the holy Koran and the holy Towrat is that there is a prophet or a messenger, who reveals from God. His name is Noah, as he knows as the second Adam. At the time of him is over-flooded by all over the world. All have died and damaged by it. There are only alive 85 people. He rules the earth for 950 years.

He has three sons. The sons are Haam, Shaam and Yaafez. The son of Haam is Hind. The son of Hind is 'Bang' who settles his inhabitants in this land. This is why this land introduces as 'Banga'.The generations of 'Banga' settle fully and forever in this land. This calls them as 'Bangal' or Bengal. At the primitive age, the name of Bangal is Bang. ${ }^{[9]}$ The word 'Bang' comes from which adds with the language of Sanskrit that 
is 'AL-racing'. 'Bang' is originated from 'AL-adding 'word into 'Bangal'. ${ }^{[10]}$ The author amazes that the word 'Ang' means the water-land and 'Bans' means water-land and 'AL or AILSE' means barrage. These three words make up of 'Bangal' such as 'Bans or Bang $+\mathrm{Ang}+\mathrm{AL}=\mathrm{Bangal}$ '. At the time of history, there are many internationals, which come here for trading, looting, travelling, settling, collecting revenues, looking for foods, preaching their religions and doctrines, living forever and taking shelter. They provide its various names for centuries after centuries. The Greeks rename it as 'Ganga'. They cannot utter it as an original in place of 'Banga'. The Persian cannot utter the word 'Sind' but in place for it they utter it as Hind. Albirroni uses it as 'Boolghakpur' that means the kingdom of the hell of the rebellions. Ibn-Batu-ta renames it as 'Dajookhpur Niamat' that means the huge wealth of the prize. The Sultan-Khiljee renames it as 'Sultan-i-Bangalah or Shah-i-Bangalah'.

The Mughals rename it as 'Subah-i-Bangalh' as their government official name. The Portuguese rename it as 'Vangala Desham'. At the time of the British renames it as 'Bengal' as for their official revenue collecting name. At the time of Pakistanese rename it as 'East Pakistan'. On 25 August in 1955, the friend of Bengal, Sheikh Mujibur Rahman tells the PCA in Karachi:" Sir, you will see that they want to use the phrase 'East Pakistan' instead of 'East Bengal'. We have demanded many times that you should use Bengal instead of East Pakistan. The word 'Bengal' has a history and tradition of its own.... We have to go back to Bengal." On 5 December 1969, to observe the death anniversary of Shaheed Suhrawardy, Mujib declares that henceforth East Pakistan would call it as Bangladesh. He added, "There was a time when evil efforts were made to wipe out the word "Bangla" from our land and map. The existence of the word "Bangla" was found nowhere except in the Bay of Bengal. I, on behalf of the people proclaim today that the eastern province of Pakistan will be called "Bangladesh" instead of "East Pakistan". ${ }^{[11]}$ There are many versatile scholars, who are born in this land. They dream a dream for being Bangladesh. The epic Alawal uses Banga as Bangladesh. The world famous Nobel winner in Bengali literature, Rabindranath Tagore uses it as Sonar Bangla in the place of Bengal. The great poet Sukanto Bhattachaya uses it as Savas 'Bangladesh' Oback Takie Roy. The poet of love and rebel against injustice, Kazi Nazrul Islam uses it as Bangladesh. The Poet, Jivananda Das uses it as Rupashy Bangladesh. In this way, the friend of Bengal, Sheikh Mujibur Rahman returns into Bangladesh. From 1971, Bangalees use it as the People's Republic of Bangladesh.

4.2 Firstfooted in Bangladesh

Bangladesh divides into two gulfs such as Sylhet gulf and Bogura gulf and it is the six corers years ago. When it sees, there are fickleness of weather, the diversification of the geographical nature and the torture of the beast and aviation in the land and in the water. ${ }^{[12]}$ The Dravidians come here at first. The Mongolians come here at the second. The Austroloids come here at the three. The Aryans come here at the four. After them, Shakas, Huns, Parthians, Afghans, Turkeys, Persian, Mughals, Portuguese, the Dutch, the English, the French, and the Armenians come here. Dr. Nurul Islam Says: Negroids, Dravidians, Tibetans, Austric, Aryan, Mongoloids, Ozur, Puru and Gangaridoy people come here. ${ }^{[13]} \mathrm{Mr}$. N. Roy says: Proto Austroloid, Proto Negroto, Proto Nordic, Veddi, Melanid and Indid. ${ }^{[14]}$ Mediterranean, Alpines, Serasonics, Arabs, and Russians come here. ${ }^{[15]}$ Why do all they come to Bangladesh? The researcher argues that they come here for trading, earning revenues, preaching their cultures-beliefs-religionsphilosophies and doctrines, travelling, exciting to the scenery, looting the wealth of Bangladesh, looking for foods, converting for their religions, making shelter for living forever, establishing their own languages and gathering the culture of Bangladesh. The fertility and abundance of land attracted many Muslims from different countries to come and settle in Bengal. ${ }^{[16]}$ James J. Novak writes for sheer loveliness, there is no land on earth more beautiful with a climate more pleasant than Bangladesh. ${ }^{[17]}$

4.3 Politicology

The scholars do not identify about the proto history of Bangladesh. Now none can discover its original homogenous. Dr. Muhammad Mohar Ali says the populations of Bengal are not homogenous in origin. ${ }^{[18]}$ The proto ancient history is in the fully darkness. All civilized people's fall-down history of the world is in covering with darkness. ${ }^{[19]}$ However, which discovers something expression by the hypothesis. At the ancient time, scholars have discovered few accounts in Bengal that is ruled by the Muriya and the Guptas. After the Guptas, the Palas dominate Bangladesh. Both of them are the original Bangalee. They follow the Buddhism. After them, the Senas and Brahmins who come to Bangladesh from the south India lead Bangladesh. They start oppressing to convert into Hinduism. After them, the dacoit and looter, the owner of Bhagabat and Bhuilee, Ikhtiar Uddin Mohammad Bin Bokhtiar Khaljee invade Bangladesh to loot the wealth of Bangladesh. He kills the Hindus at a random. He captures the palace of Bangladesh in 1204. The king Lokkon Sen and his two sons Biswarup Sen and Keshob Sen escaped away from his palace. He is a designated Muslim but he does not preach Islam in Bangladesh. After looting wealth of Bangladesh, he is 
going to invade Tibet. In the middle way of invasion, he and his followers quarrel one after another for division of the looting wealth.He is killed by his accompany Ali Mardan Khaljee. The Muslims divide into five sections in Bangladesh. They are Khaljee, Sultans, Mughals, Nawab and Pakistanese. The English rule Bangladesh from 1757 to 1947. Khaljee, Sultans, Mughals and Nawabs are snatched away the language Bengali of Bangladesh. They import Arabic, Persian. Arabic is their religious language and Persian is their court language.

The English import English, Arabic, Persian, and Sanskrit. English is their court language. The Khaljee, the Sultanates, the Mughals, the English and Pakistanese import Urdu, Arabic, and English. English is their court language but Arabic is their religious language and Persian is their researching language. Urdu is their state language of Pakistan. Bengali is the mother language of Bengalee. The pact of Sharat BoseShuhrawardy is vacated by the misinterpretation of the Hindu-Muslim movement where both of them think a wrong idea. The Muslim League try to make their Muslim solidarity and the Congress also retries their Hindu domination of Bengal. For this reason the greater Bengal does not make as a strong unity. India and Pakistan becomes independence with a writing recognition impact. From the beginning, The Pakistanees start their colonial ruling as the English. They think that Bengali is the language for the Hindu. The people of Bangladesh start fighting against them to regain their mother language from 1948 to 1952. On the way of mother language commotion, they become independence as a nation in the world map as Bangladesh. There is not to keep up East Pakistan. It renames it as the Independent Bangladesh. The author seeks that how they want to establish the kingdom of the creator as God. All have wanted to found their religious doctrines. How they want to establish about their religious owner.

4.4 Allah

Allah is One and Oneness supper and supper action. 'Allah' the word comes from, in Israelite/ " $E l$ " and Akkadian is "Ilu" and is particularly close to the common Hebrew term "Elohim" and the less frequent 'Eloach '. ${ }^{[20]}$ From 'Elah' comes Allah. Allah is the Arabic equivalent of the English word God, and is the term employed not only among Arabic speaking Muslims but Christians and Jews and in Arabic translations of the Bible. " ${ }^{[1]}$ A contraction of al-ilah meaning "the god," Allah is cognate with generic pansemitic designation for "God" or "Deity". ${ }^{[2]}$ On the other hand Allah (allah, al-ilah, the god) was the principal, though not the only, deity of Makkah. The name is an ancient One. It occurs in two south Arabic inscriptions, one a Minaean, found at al-Ula and the other a Sabacan, but abounds in the form HLH in Lihyanite inscriptions of the fifth century B.C. Lihyan, which evidently got the god from Syria, was the first centre of the worship of this deity in Arabia. The name occurs as Hallah in the Safa inscriptions five centuries before Islam. ${ }^{[23]}$ In pre-islamic Christian Arabic inscription found in umm-al-Jimal, Syria, and ascribed to the sixth century ${ }^{[24]}$ where "Aliha, Ilaiha" means He took himself to Him for refuge or protection; He sought or asked aid or succour of Him and "Allahatun" means He reckoned Him among gods and that is "Ilahun" means an object of worship or adoration i.e. a god or deity; and "Alihatun" means two gods. ${ }^{[25]}$ The main word Hallah. "H" is lapsed from Hallah when the ancient Arabian utters Hallah. That is from Allah which is the name of the Supreme Being. In Arabic language, this word is never used for any other being or thing. No other language has a distinctive name for the Supreme Being. "Allah" is always used in the singular. ${ }^{[26]}$ Sibwaih and Khalil say: Since ' $A l$ ' in beginning of the word Allah is inseparable from it so it is a simple substantive, not derived from any other word. ${ }^{[27]}$ Allah means Creator. 'Allah' the word has no grammatical rules and regulations that grammar is man-made.

The supreme creator, Allah says in the holy and the glorious Koran: "Say: Allah is One, The eternal God; Allah begot none, nor was Allah begotten. None is equal to Allah." ${ }^{[28]}$ Besides, we use the word "Khoda " by the synonym of Allah. This word is used for worshipping to the sun or Fire but the persons who are engaged to pray to the sun, they are called their God as Khoda. All should give up these to follow and to use-practice in our life by the teaching of Allah. To see, Muslim scholars believe that Allah terminates into the affirmation of male. For understanding, they deny the importance of the equal rights of the women. This causing they do not use 'Allah' as 'She'. However, all Muslim scholars use Allah as 'He' as the pronoun. The Muslim scholars use God in bad effect such as Godfather, Godmother, and Tin God. To see, there is a very interesting part. They use Allah such as Asad-Allah, Rafiq-Allah, Abd-Allah, Saif-Allah and so on. All have to identify what the word all should use for the creator. The researcher believes that God or Allah is the same connection. Moreover, Muslims use Allah and He, who is the Oneness Creator and the male are the greatest like Allah or God. Except Islam, all use God or Goddess and She because men and women are in the equal on the eye of Allah or God. Therefore, Allah is the limit-less-encyclopedia out of the whole universe that is man-made from the mankind and womankind and super-natural beings. ${ }^{[29]}$ 


\section{Theology}

The main speech being about the subcontinent of India, the Aryan, the Huns, the Semantics, the Karthians, the Turkeys, the Greek, the Persian, the Middle East-holders, the Mughals and the English who come here and this is why they carry a new theory here one after another ages. From where there they cultivate their theories how it can re-develop their desired aspiration to loot the origination of the Vangla. They will not only do agricultural-farming livestock but also they come to Vangla and try to convert the Vangaleese. The Bengalese, who accept their concepts, who know as the best of them, who they do not take their doctrines. They are known as the atheist or Nastic and Aosur or Mahisasur or touchable and untouchable in the Vangla track, the whoever come to Vangla because this land is free from darkness as we can point out in feedback into the pre-Islamic Arab, and there needs a prophet to get rid of injustice and inhuman. It is obvious that pre-Islamic Arab is not only the land of savagery, barbarian, and in-humanism but also the fond of culture. In this line the sub-continent of India is free from that this reason here needs not prophets. This quoting may be right or may not be.

The supreme creator has sent a great number of Rasul or Prophet or Ovater, Deva or Devi or Rishi or Preceptor or God or Guru, Saai or Mahasay or Ustad or Guruma to show the getting rid of the best path in the mankind and womankind of the world where they make their land for housing and living. It proves that Allah has sent and revealed those types of great men and women to the every township of the globe. On the discarding of re-thinking, we can invent the Upa-banga or Bangla or Bangal's nomenclature. The history does not sit here motionless to discover the inhabitants of this beloved land who dominate here and this is why here cannot provide the answering equipment for this quested matter. Many historians opine many opinions. Some believe the Bangla ruler is the pro- son of Noah this king is Banga. Some rethink this area surrounds by Bans.

'Vans' is a Tibetan language which means the staged watered land by forests in the lower parts as the Bay of Bangal. To imagine in finding out latest finding is in the Veda that is the holy book of the Bedantists. This scientific element is in the Veda 'Bangabhuvanashidham' in the page 1099 in 2008, which depicts. The language of Santal 'Banga' means the land of God, Gods, Goddess, or Goddesses.

We can mention 'Chandvanga' and 'Shingvanga'. In the eternal part of the history of Bengalee lies from the West Bangla, Jolpaishiriguri, Assam, Tipera to the East Bangla. Today they deduct from their part of their organ. The Greeks rename to them Banga-Deshai, the Sultans rename them Banga-la but they add 'Ala' Arabic word and the Mughals rename to them as Suveh-Bangla. At last the English rename to them as Bangla or Bangala and the Pakistanees rename to them as East Pakistan. The friend of Bangal Sheikh Mujibur Rahman renames to the East Bangla as Bangladesh. It clears that Bangladesh is made up of from 'Ban or Bans + Ang + AL'. The Greeks who rename to Bangal or Ganga as the name of the river Gangetic that is rename as Gangariddhi turning into Bangaladesh. The takers of their doctrines know as Pala patronized them in few. The people of the north India are known as Sena come to Bangal or Bangla and they attempt to found the religion regarded as Sanskrit. The Aryan and Arabs Sultan invaded and looted Bangla or Bangal.

They do not go back to their homeland but the thought Bangla becomes their everlasting living land as motherland. They patronize Bangla as the literature based language but they declare that Arabic is their religion and Persian is their court language. The Mughals come, capture and Bangla becomes their earning sources of their treasure and revenue regarded as their Suveh-Bangla. They patronize their Persian language as the court, Arabic as the religion language and Bangla as the source-translation language. The Portuguese, the Dutch, the French, and the English come to Bangla or Bangal as like above them. The English rename to Bangla or Banga or Bangala as the Bengal. The English create English as their court and business language. At the last, the West Pakistanee aggressive soldiers and the few Bangaleese followers of them try to retry to re-establish the court language as Urdu, Arabic, and Persian as their religious tongue. Under above these Aryans create here: One-side is Brahmin, Baishnava, Khatrya, Patni, Sudra, Touchable , Untouchable , Dolit, Muchi, Chamar, Chandal, Horizon, Taati, Adivasi , Guru, Saai, Mahasoy, Purohit, Tagore, Uchu, Nichu, Kulin, Biswas, Mandal, Okulin, Methor, Dhopa, Rojok, Rojokini, Rishi. Second section are Munshi, Moulavi, Beg, Dhalli, Khan, Shayyakh, Sayed, Sher, Molla, Pir, Sufi , Darvesh, Shaykh, Alem, Mir, Bakshi, Khalasi, Ulema , Hazi, Ajlaf, Atraf, Gani, Gazi , Munsef, Kanungo, Tahsilder, Zamindar, Payeek, Piaada, Kayal, Shikder, Pathan, Jagadiswar, Dilliswar, Bhumiswar, Maheshwar, Bhuvenswar, Parameswar, Peshkar, Sherestader, Podder, Mulluk, Malik, Jahapana, Gustahki, Maf, Allama, Maulana, Piraly, Jola, Sarkar, Nikery, Malabar, Kolu, Imam, Dhali, Biswas, Mandal and Hoojoor. The third section are one is Magistrate, Commissioner, Deputy 
Commissioner, Collector, Landlord, Barabhuyan, Bhuyan, Gomostader, Chaklader, Howlader, Jotder and Gatider. First class and second class are in it.

The third class is known as Jon, Mahender, Bhritye, Das, Mattubbar, Dasi, Chakor and Chakrani. Both of two high sects hate third sects in one after another and they may Vedandaist, Hindu, Buddhist, Muslim ,Khilji, Din-i-ilahi, Majam-ul-baieren, Bahai, Kadiany and Christian and many other folk-religion such as Bhagabania , Baaul, Baishnava, Matua, Istopransantsanga, Hari, Piraly, Dharma Tagore, Manasa Mangal, Dhatry, Ganesh Pagal, Brahma, Shahebdhani, Pir-ism, Navavidhaan, Ram Tagore Dharma, Raash Puja, Kattyany Puja and Kartabhaja.

By the ruling of the Sultans, Ghure, Khilji, Mughals, Nawab, Pir, Sufi, Olee, Mufti, Muffassir, Mujaahid, Fakih, Mujtahid, Amir, Naebe Amir, Naebe Rasul, Adib, Kabar, Shawsan, Kafin, Kafan, Middle East holders businessmen, they have swayed the Muslim administration and becomes in refiguring into the Sheikh Mujibur Rahman founded as Bangladesh today it is an emerging tiger in Asia. The researcher has seen the picture of anti-religion. It is not a pen-sad and so much pathetic. Today Non-Aryans are only the foreigners in their motherland, in this Bangladesh swaying on the last civilization, who are the greatest sons and daughters. The races of Aryans declare: They are only the uncivilized, Nastic-Moortaad-KafirMushrek, Munafik, Gumrahi, Bidharmi, Amuslim, Hindu and the race of the birds. World religions do not accept the theory of them in that cases he can amaze that all religions on earth are in the real exposition that many of us don't know but only understand that the persons who follow the doctrines of the eternal religions which are man-made. All religions preach the universe peace for the world and he believes all religions are in human-ism.

Allah says: "There shall be no compulsion in the religion." ${ }^{[30]}$ Allah says more about the global languages and religions and colors: "And of Allah's signs are the creation of the heavens and the earth and the diversity of your languages and your colors." ${ }^{[31]}$ On the contrast of timing of view, all founders of the religions are man and woman in this line. It can find out and re-say that the scriptural religion, which is followed by the most people of the areas patronized by governments to re-shape and re-make the mankind and womankind for the development of the nations of the globe which are called as Divine religion. It is a great sorrow that these religions, which follow up in the two or more people that they do not accept and accredited by any state ruling, calls as the Un-divine religion or folk-theology. As a result whose followers are in few and rare, they are not scriptural or divine religion or folk-theology or secularized religion. Islam has not that things today that is accepted the Islamic Schools. They are many Islamic schools. They are Hanafi, Maleki, Shafeii, Hamboly, Shiiate, Kurdy, Jabariia, Rafegy, Murjiia, Mujjachama, Murtihidia, Kharejii, Mutajiila, Assariia, Suffa, Ashabe Suffa, Piriism, Tasawaaf, Karamatia, Wahabi, Tarikat, Mariifat, Hakkikat, Waaziism, Jihadism, Deobandi, Kalandia, Mujjaddia, Chistia, Nakshabandia, Kaderiia, Wahadatul Wazud, Fanafillah, Barjakullah, Furfuria, Jounpuria, Ajmiriia, Bhandariia, Khan Jahan Hazee, Gazee, Khondokar, Piraly, Charmonai, Manikganjia Siddik Nagar, AtRashi, Shah Makhdumi, Fooltalee, Ahasania, Pirjaada, Gaus, Kutub, Nakib, Abdal and Mazaarian, Buno, Bagdi, Bagri, Shaitan, Jaalem, Shawrga, Behesta, Dojokh, Narak, Aain, Adalat, Bichar, Majlish, Khanka, Ashram, Dham, Mandir, Temple, Masjid and Pathshala sects and so on. They are made them to need as the timing as designed by the rules of Islam but it is not refigured into Mhammed made Islam and they only expect to get rid of the men and women from the path of the darkness of the globe. Many Muslims have made the new religions such as: Bahai, Kadiyani, Baaul and Pirism named as Ulama, Mashayakh, Shayakh, Olee, Awlia, Kibla Baba, Hujur Kibla, Pir Kibla, Doyal Baba, Abba and Mujjaddidey Jaman. One-day men and women deny the man-made theory in the ancestral theory and they will invent the novel theory to remake and reshape their life in newly and newly.

From today before the eternal past men and women, lead their life by remaking their theory for unknown times as trillion years. The scientists, anthropologists, sociologists, archaeologists and inventors try away to discover the real facts by their scientific hypothesis. As a reviewer, he can redefine between the large theology and folk-theology. All preceptors of the theology and folk-theology have parents who take birth by them as the general personalities in the world but they have only a novel theory, which have not expressed and preached and invented by any more, and they are the prophets of the people. In this regard, Men and Women can vary and this is why there is a great difference among the novel theory explorers and theological and folk-theological thinkers.

The global societies have an undetermined numbers of sociological, anthropological, and cultural classes which are man-made and re-man-made theoretical concepts. Now he will try to prove the faith and cast-ism in our Bangla in the varieties numbers. One caste, Jola that means Muslim-weaving class does not provide the marriage with others in Muslim class. Here has a cast-ism renamed as Taaty that means Hindu-weaving 
class. They cannot connect a marriage system with another caste. Not only Jola and Taaty but also Hazam, Kahar, Kalu, Dom, Methor cannot entertain, connect and marry with one after another. The Hindu society also does not engage into marriage system today in Bangladesh. It is not only Bangladesh but also in The Kingdom of Saudi Arabia. The Saudi Arabians who are the world greatest humanism as Islam but here is Non-Arabian who cannot marry any Arabian daughters. It seems that they are not the real fascism. On the other hand, it is hated as cast-ism? In this lines Bangla non-sectarians Muslims such as: the followers of BNP, BAL, JASAD, BASAD, Islamic Shaswantantra Andolon, Jaamaate Islamic Bangladesh and Jatya Party. In 2018 the election commission has expressed a gadget to ban the registration of Jamate Islami Bangladesh. The special sectarian Kaumia Madrasha educators affirm to marry with the same followers. It is also a hated cast-ism with the name of Islam. The researcher has to retell about them that they are not only the notorious killers of the real Bangla nation but also they get condolence in receiving foreign theology which are being used for ascending into the Bengal palace where they are all busy to remake capitalism and theology which is closely bondage with one in one. The womankind is the first producer from dawn of the civilization. She makes up friendship, best-seed, family, society, cultivation and all kinds of peasantry work and production theory. Today she is fraudulent by the patriarchic ruling. The mankind has snatched away their all power. In 2018 Bangladesh, prime minister is trying to get returned the womankind's empowerment in all sectors in few.

In gender equity, the mankind should return their all power in the sociology; politics, economic power, theology, interculturology, administration, family studies, sport studies, international studies and all sectors in the world. The Bangla tradition and culture believe that all men and women are equal in controlling the earthly and spiritual moral life. Here is no difference against humankind and womankind. On the historically exploration of the Muslims rulers in Bangladesh, the Sultanes, the Mughals, the Pakistanese, BNP and Jatyo party who rule Bangladesh, they come from the military institutions by killing people and firing the peak in high by the guns. In most cases there be will pointed out about the accounts of them. In Bangladesh, the Muslims kill 30 million people from 1204 to 1947 C.E.

From 1947 to 1971, The Muslims kill 3 millions ${ }^{[32]}$ people. About 400000 women and girls ${ }^{[33]}$ become raped and become pregnant by the Islamists, Pakistanese, Rajakars, Biharis, Albadars, Ashsams and Asshsaheen. About 10 million Bengalees leave their motherland and 10 million Bengalees are in fugitive. After 1971, the friend of Bengal, the founder of Bengal, Sheikh Mujibur Rahman establishes as Bangali Nationalism where all religions are in equal. None can play a religious politics according the 38 article of constitution of Bangladesh. At the time of Pakistanese: In 1949, the central minister for education urges: Not only Bengali literature, even the Bengali alphabet is full of idolatry. Each Bengali letter is associated with this or that god or goddess of Hindu pantheon...Pakistan and Devanagari scripts cannot co-exist.

It looks like defending the frontier of Pakistan with Bharati soldiers...To ensure a bright and a great future for the Bengali language, it must link up with the holy Quran...Hence the necessity and importance of Arabic script. ${ }^{[34]}$ And more point-able is Urdu was to be the medium of instruction of primary, secondary, and tertiary levels of education and the Bengali script was to be replaced by the Arabic script. ${ }^{[35]}$ In this position, Bangladeshi people start thinking for their actions. The Pakistanese more declare: Secularism does not mean the absence of religion Hindus will observe their religion; Muslims will observe own; Christian and Buddhists will observe their religions. No one will allow interfering in others religions.

The people of Bangladesh do not want any interference in religious matters. Religion cannot use for political ends. The persons who are East Pakistan who want to get job, they have to learn two languages such as Urdu and English. ${ }^{[36]}$ The four sections are in all for all. They are: a. Communalism in all forms; $b$. the granting by the state of political status in favor of any religion; c. the abuse of religion for political purposes; and d. any discrimination against, or persecution of persons practicing a particular religion. ${ }^{\text {[37] }}$ Here BAL discovers that all are equal in the dictation of the supreme creator God. This is why BAL stats: No person shall have the right to form or be a member or otherwise take part in the activities of, any communal another association or union, which in the name or, on the basis of any religion has for its object, or pursues a political purpose. ${ }^{[38]}$ In 1972 the constitution of Bangladesh: "Joi Bangla" slogan is as the same of India "Joi Hind". It is a Bengali Nationalism because Bangla is a son of Hind. History says that. To keep the dream, Sheikh Mujibur Rahman desires to make the Bengal of golden.

The Islamic assassination groups kill him as the name of military cue in 1975. Major Zia Ur Rahman deletes Bangali Nationalism. He makes up BNP and he plays an election with name of democracy such as 'Yes or No". The BNP amends the 1972 constitution by more tearing and tapering in many times. They ban secularism. He declares Religious belief and love for religion are a great and imperishable characteristic of the Bangladesh nation. ${ }^{[39]}$ By the proclamation of order No-1 of 1977, the ideal "Bismillah-ar-Rahman-ar 
Rahim" inserts at the beginning of the constitution above the preamble. Absolute trust and faith in the Almighty Allah, Nationalism, Democracy, and Socialism meaning economic and social justice together with the principles derived from them shall constitute the fundamental principles of state policy. ${ }^{[40]}$

Mr. Ziaur Rahman thinks: "Joi Bangla" slogan, which is akin to the Indian slogan as "Joi Hind" which is de-placed by Mr. Zia as "Bangladesh Zindabad". "Zindabad" is an Urdu word that means "Long Live" that is closer to "Pakistan Zindabad". He more declares the elements of Bangladeshi Nationalism are Race, the war of independence, the Bengali Language, Culture, Religion, Land, and Economy. He establishes Liberal Islamic Nationalism. The word "secularism" deletes and a new provision incorporated to place full faith in Almighty Allah. "Struggle for national liberation is replaced by the "War of National Independence". "The "Islamic Idea of Social Justice" is replaced of "Socialism". ${ }^{[41]}$ Mr. Ershad places into the state power of Bangladesh. In 1983, he tries to establish "The Islamic State". His Islamization policy is in two: a. Mosque-centered society; and b. Islam as the state religion. He starts visiting to the difference at Pirs in Bangladesh. He declares that Islamiat and Arabic would study as a compulsory subject. $\mathrm{He}$ encourages Madrasha education and Imam training program. Islam is the state religion then it becomes the sovereignty power. The Bangladesh state must recognize the plurality of its culture and people. The political elite whips up religious fanaticism for its own vested intends. In 2008, BNP and Jamat-i-Islami state that if elected it would be enact a "blasphemy law" to prevent anti-religious statements and criticism of religion in books, newspapers, and electronic media. Jama-i-Islami trains citizens aged between 20 and 30. ${ }^{[42]}$ For this reason, today the extremists and assassination groups have produced at a high scale. In 2001, Jamat-i-Islami Group creates Islamic groups such as "Islami Chatra Shibir and Huj-i-B gain legitimacy within the political landscape of Bangladesh." The existence of Islamist militant groups are such as JMB, Har-Kat-ul-Jihad, and Jihad-Al-Islami-Bangladesh. BAL descends into state power with taking the people's mandatory. From that time, they rule and make Bangladesh as the middle-income country in the world. The High Court declares to regain the 1972 Constitution.

The parliament passes it with all yes votes to accept the 1972 Constitution. Then all Islamic parties in Bangladesh have banned. After this fact, the Islamic groups start to connect with the International terrorist groups such as IS, MBH, AQT and unknown assassination groups. They want to kill other religious people and they only want to lead to Bangladesh. These groups, which add into above-mentioned them and they are Ansar-Al-Islam Bangla team, Allahar Dal, Hijbut-Tah-Rir, Huji and Mastura Jamat. The present BAL government starts a fight against them as zero tolerance.

Historically Bangali culture as we have seen is mainly inclusive, tolerant and syncretism in nature ${ }^{[43]}$ There have been isolated incidents in which militant Muslims called upon the Buddhist to leave the country and settle in Myanmar. ${ }^{[44]}$ In this way, he religious actors try to establish the dictation of God. Especially the Muslims assassination groups create a religious conflict only for gaining the state power. All religions in Bangladesh are equal in the eye of BAL and 1972 Constitution. The Muslims are in desperate in nature. They want to capture only the state power. They differentiate into many sects. They are Sunni, Ahale Hadith, Shia and Sufism. However, none can tolerate one after another. Sufism divides into many sects. They call as Pir in Bangladesh. They are many Pirs in Bangladesh. They are Aatrashi in Faridpur, Charmonai in Barisal, Sarsuna in Patuakhali, Chandrapuri in Madaripur, Sureshawri in Chandpur, Foorfoora in Pabna, Fooltala in Silhet, Dewanbagy in Dhaka, Manikganj in Manikganj and Majbhandary in Chittagang. The Charmonai orders that Aatrashi is not an Islamic Pir. Other orders that Charmonai is not an Islamic Pir. The Baaul sect is not an Islamic Sufi. Sufism is shaping the country's open religious atmosphere. They call them as the folk Islam. They are 90 percent now. However, all find out God. There are many sects in Hindu. These are created for deception, oppression and torturing by castes-ism which is produced by Brahmins. These sects are in Bangladesh. They are Bhagabania, Matua, Istopran Satsanga, Balaram Hari, Kubir Gosai, Kishorebhoja, Maababa, Vaishnava, Sahajia, Jogamohini, Thakurbani, Madada, Khepadal, Doyamoy, Ramthakur, Satyadharmy, Bhavapanthy, Pagalpanthy and Ganesh Pagal. They call them as the folk-Hindu religions. The Hindu sect is 9 percent. The Christian and Buddhist are in a serious minority. They are 1 percent. The Buddhist is in two divisions. They are Hinjan and Mahajin. The Christian is in three divisions in Bangladesh. They are Catholic, Protestant, and Church. They compromise different denominations in particulars Catholics, Anglicans and various form of Protestantism, such as Baptism. ${ }^{[45]}$ Above-mentioned religions, there are three religions in Bangladesh. These are Kadiany, Baha'i, and Krama. The extremists Muslims declare that Kadiyani are not Muslim. They work in a silent nature for fear of the Muslims.

There are 300000 people who are Baha'is animists or indigenous peoples, who practice other beliefs or traditional forms of spirituality in combination with one of the four religious mentioned above, affecting 
Hindu people who had, converted away from Hinduism to another religion, for instance, the Baha'i faith.

${ }^{[46]}$ Krama is a new religion in Bangladesh. The Mro indigenous people, who traditionally practice Buddhism some tens of thousands have turned to a really founded religion named "Krama". "47] Bangladeshi educational system is in three sections. They are government, Private and Individuals. The government education is in revenue, autonomous, developing, and projected. The government education is two types. They are General and Madrasha. There are about 9000 Madrashas, which grant by the government. These Madrashas are government and developing sectors. These kinds of Madrashas know them as Aalia. There are about 27 thousands Private Madrashas which are not granted by the government. These Madrashas know them as Kawmia. The individuals lead these. Here teaches only Arabic, Urdu, Koran, Hadith and related some grammar. All want to play the rules of God.

Here are many types of God theory. Muslims say their creator as Allah. They believe that the disciples will go to the Pir or Sufi. They will take them to the prophet Mohammad. Mohammad will take them to the creator God. Hindus say their Creator as God or Goddess such as Brahma, Bishnu, Shivam, Ram, Krishnan, Radha, Bhagaban and Iswar. The Buddhist believes that honest work is God. Christian believes that the creator is God. There are no Jews in Bangladesh. The researcher thinks that the Muslims, who rule the state power, when they add religion with their state power, there have hampered a religious conflict. They have not only tried the other religion from their country but also they have killed the own religious people. They want to stay for ruling state by killing people at a random.

\section{Result}

The religion, which has added into the state power, there, has framed as the religious conflict. The Muslims, when they start adding into the state with their religion, Omar, Osman, Ali, Hossain and thousands of Shabee who has been killed by the Muslims. The follower of Mohammad, Sahabee Mamun, Muhaimin, Sahabee Abu Wakkas come to Bangladesh. At the seventh and eighth century, Hamed Uddin, Hossain Uddin, Mohammad Mortoza, Mohammad Abdullah, and Mohammad Abu Taleb come to preach Islam to Bangladesh. ${ }^{[48]}$ Moreover, there is sad news. From 1414 to 1430 C.E., The Muslim ruler, Jalal Uddin declares to the Hindu: Either you convert into Islam or you will be prepared for death. ${ }^{[49]}$ The Muslims have preached Islam in Bangladesh by the compulsion and by the sword. The Zinda Pir Awrangzeb kills the undetermined number of people when he rules Bangladesh. Many people convert into Islam. They believe the Pirs because they would: a miracle power, cure diseases, provides babies who cannot produce them, win the death, provide life from death, and provide rain when it is need and a great power like the creator. ${ }^{[50]}$ For this reason, many causes create religious conflict in Bangladesh. There has been occurred uncovering by the military political power. The consciousness of Bengalee has to be ruined. The abroad religious dominant and the cultural servitude swallow the society. There has been gone on looting by the foreigners for age after ages. By looting up of all wealth of Bangladesh where makes up the Persian empire, the Arabs empire, the Turkish empire, the Greek empire, the Ghazoni empire, the Sultanates empire of Delhi, the Mughals empire, the English empire and the Karachi empire. From 1958 to 1971, military ruling, economical parching, the eviction of the culture of Bengalee and the administrative deception go on at a high alarming rate. After 1975, here goes mad on the militant policy in the great enthusiastic religion. For this furious contradiction, there inlaid on power playing games, refuting and tearing the constitution of Bangladesh and perverting the history of freedom fighting of Bangladesh.

On the other-hand, the half of the people of Bengalee is woman. All they have to keep under the darkness of the religious curtain into the hearth of the house-land. They mistreat the exploring the religious perception unlimitedly. There is to run by azure policy. The women can't use up their all kinds of activities and liberties. This situation snatches away their economic power, their political power, social power, administrative aspects and rights, religious rights, their contributed aspects and gender equity from them in the way for nip in the bud. That so-called situation declares: Women can't fulfill active like the men. The military ruling power hobnobs with black pitch to their belly as regarded women. All women can't travel and visit roads, vehicles, cities, towns independently.

There does not think about their gender equity and the freedom of women like men. The supreme creator, Allah says in the holy and the glorious Koran: (a) "O Adam! Dwell you and your wife in the garden and enjoy (its good things) as you [both] wish: but approach not this tree or you [both] run into harm and transgression. Then began Satan to whisper suggestions to them bringing openly before their minds all their shame that was hidden from them (before): he said "Your Lord only forbade you this tree lest you [both] should become angels or such beings as live forever." And he swore to them both that he was their sincere adviser. So by deceit he brought about their fall: when they tasted of the tree their shame became manifest to them and they began to sew together the leaves of the garden over their bodies. And their Lord called 
unto them: "Did I not forbid you that tree and tell you that Satan was an avowed enemy unto you?" They said: "Our Lord! We have wronged our own souls: if you forgive us not and bestow not upon us your mercy we shall certainly be lost." (Allah) said: "Get you [both] down with enmity between yourselves. On earth will be your dwelling-place and your means of livelihood for a time."

He said: "Therein shall you [both] live and therein shall you [both] die; and from it shall you [both] be taken out (at last)." O you children of Adam! We have bestowed raiment upon you to cover your shame as well as to be an adornment to you but the raiment of righteousness that is the best. Such are among the signs of Allah that they may receive admonition! O you children of Adam! Let not Satan seduce you in the same manner as he got your parents out of the garden stripping them of their raiment to expose their shame: for he and his tribe watch you from a position where you cannot see them: We made the evil ones friends (only) to those without faith." [51] Allah says in the holy and the glorious Koran: (b) "And we have enjoined on the person (to be good) to his/her parents: in travail upon travail did his/her mother bear his/her and in years twain was his/her weaning: (hear the command) "Show gratitude to me and to your parents: to me is (your final) Goal." ${ }^{[52]}$ Allah says in the holy and the glorious Koran: (c) "We have enjoined on the person kindness to his/her parents: in pain did his/her mother bear him/her and in paid did she give him/her birth. The carrying of the (child) to his/her weaning is (a period of) thirty months. At length when he/she reaches the age of full strength and attains forty years he/she says "O my Lord! Grant me that I may be grateful for Your favor which You have bestowed upon me and upon both my parents and that I may work righteousness such as You may approve; and be gracious to me in my issue. Truly have I turned to you and truly do I bow (to You) in Islam [submission]." [53]

Allah says in the holy and the glorious Koran: (d) "When news is brought to one of them of (the birth of) a female (child) his face darkens and he is filled with inward grief! With shame does he hide himself from his people because of the bad news he has had! Shall he retain her on (sufferance and) contempt or bury her in the dust? Ah! What an evil (choice) they decide on!" ${ }^{[54]}$ Allah says in the holy and the glorious Koran: (e) "O men, women and the third gender! We created you from a single (pair) of a male and a female and made you into nations and tribes that you may know each other. Verily the most honored of you in the sight of Allah is (one who is) the most righteous of you. And Allah has full knowledge and is well acquainted (with all things)." ${ }^{[55]}$ Within this way, they think if they die, their death will be martyrdom, if they can kill other to found Islam, it will be a good act for entering the so-called heaven, if they can win, they will be a win fighter. These types of things are teaching them by the Islamic Jihadists. These Jihadists and Islamic assassination are playing a hit list criminal killing mission from 2013 to the present. They have targeted to the foreigners, other religions, Hindu, Buddhist, open-minded people, secular minded people, liberal minded Pirs who are to follow the various folk-religious schools in the name of the frame the Bengal original script for practitioners as religion.

The facts of the Ramu, the Sholakia, the Holiartisan, the Pabna, the Rangpur, the Sirajganj and the Jhenaidah are very moving sight. These events are the main culprits for the world human-ism and womanism. They say that these actions are to get meeting the creator God. God has taught them in the holy Koran. This type of God, does he found Bangladesh by killing people? No. God is omnipotent, omnipresent, Omni-loving and Omni-kind. He does not suggest killing people who has created the whole universe. The miss-explainers have explored its own-self. The Bangladesh Awami League is trying to found the Golden Bangladesh for all religious holders but none does try before Bangladesh Awami League. The present BAL tries to use the Kawmia nesab education system and prime minister's Sheikh Hasina government has given the MA equivalent scale to Dawraye Hadith, they have been working for women empowering, they have acknowledged the Hefajote Islamic party, they have been passed the women friendly laws and ethics by the constitution, and they seem it is their vote bank. The Bengal women try to get admitted into working beside with the men. They play a vital role in government, administration, games and sports, army, navy, air-force, police, BGB, education and in all sectors they try to cover the full term in this case social, political, religious, economic and cultural development in Bangladesh where there seems Bangladesh is like an emerged country in the Asia.

6. Conclusion

In summing up, all are to identify about discovering God in Bangladesh. Bangladesh has own religion. An undetermined numbers of foreigners come to Bangladesh from the various parts of the world. They come here, rule here, preach their religions, doctrines and philosophies, settle here, look for foods here, shelter here, travel here, trade here, export here, import here, marry here, excite here, collect wealth here and so on. They use their creator as various names. All have to lead their state power with the connection of their religions. In Bangladesh, who wants to found religionization, they have killed people to capture the total 
state power. The researcher has studied the history of Bangladesh. He has seen that all rulers in Bangladesh have captured the state power in relating with the name of God. To see, the Khaljee, the Sultanese, the Mughals, the Nawabs, the English, the Barhbhuyans, the Pakistanese, the BNP, the Jatyo Party and the Islamic Parties what they wanted before and what they want the present. He thinks and believes that if Bangladesh becomes secularism, here will not kill the people at a random. All should differentiate religion from the state power. Religion is up from all over in the earth. All should believe that God or Creator or Allah is for all in equal in Bangladesh. He amazes that the upcoming generations who will rule the state; they do not use religion with adding the state power. Here researchers, scholars, readers, critic, scientists, rulers, politicians, and students find out a new path to remake their God theory in Bangladesh. All nationals in the world provide a re-flourishing wave how to found God philosophy in their countries. He minds that all cultic dynamics radicalization will forget forever the anomaly theory of IS, AQT and the religious conflict in the Middle East, Europe, Asia and Africa. Where there are killing all kinds of people as devastated at a high rate, where there is no humanity and humanitarian because the religious actors have been dogmatic for killing, killing, killing and killing...Where is the humanism religion, God! Why the Muslim world is in silent?

Acknowledgement

All praise to the supreme God who has created him as a human where has kept him healthy and acknowledges his mother Mouree Begum and his father Md. Noab Ali who have produced and fostered him to learn the differentiation from the discrimination of this religion conflict among the holy Koran, the holy Bible, the holy Veda, and the holy books are great sources for him from where he has learned the religious theory to differentiate between false and truth. He is very indebted to the Professor Dr. Mahfizur Rahman Akhanda who guides him to study this article with the best cordially.

Prof. Dr. RKM Saleh and Prof. Dr. A.H.M. Aktarul Islam, who influence me to study this research topic with a great accented archive and the researcher's study will be incomplete if he does not acknowledge the credit of his forever life companion where I owe a debt of gratitude to my wife, Shapla Khatun, for assisting me in very practical, but ultimately crucial, ways from the start, and for her encouragement and devoted patience throughout this project, all of which kindnesses were offered with characteristic generosity because when he studies the problem, they keep patient his gaps and they provide him a great inspiration to study this paper. His daughters, Kity Zemini, Kity Zoomaina and sons Mr. Nazmus Sakib and Nazmool Arefin who are busy to study. They all always keep patient for his filling and is very indebted to the martyrs and freedom fighters of Bangladesh because they have been independent Bangladesh and it helps inspiration to study this type of paper.

References

[1] Rahman, Mahbubur, "Bangler Itihas", (Bangladesh, Dhaka: Book Fairs, January, 2014) P.28

[2] Chowdhury, Dr. Momin, "Prachin Banglar Itihas", (Bangladesh, Dhaka: Mowla Brothers, March, 2012), P.14

[3] Sen, Sukumar, "Bangladesher Namer Puratatty", Itihas Rakkha, No-9, India, Kolkata, 1365, BY, PP.34-35

[4] Islam, Sabiha, Khalil, Dr. Md. Ebrahim, "Sawdhin Bangladesher Avbudoyer Itihas", (Bangladesh, Dhaka: Merit Fair Publication, May, 2014), P.1

[5] Islam, Seyed Amirul, "Vangla Anchaler Itihas", (Bangladesh, Dhaka: Papyrus, January, 1996), PP. 10-13

[6] Islam, Dr. Md. Nurul, "Bangladesh: History, Culture and Heritage”, (Bangladesh, Dhaka: Tasmia Publications, Reprint, June, 2012), P. 23

[7] Rahim, Dr. Abdur, et al., "Bangladesher Itihas, New Edition", (Bangladesh, Dhaka: Nowroze Kitabistan, 2003), P.17

[8] Rahman, Dr. Atiar, "Dokkin Banglar Avijat Sreni", (Bangladesh, Dhaka: Katha Prakashani , February, 2010) , PP.23-24

[9] Salim, Gholam Hussain (Trans.) Akbaruddin, "Banglar Itihas", (Bangladesh, Dhaka: Abosor Publication, February, 2008), PP.23-24

[10] Fadal, Abul, (Trans.) Bandapadhya, Pachkari, “Ain-i-Akabary O Akbarer Jivanee”, (Bangladesh, Dhaka: Dibbyo Praksh, February, 2008), P. Amarkatha

[11] Rahman, Sheikh Mujibur, "The Unfinished Memoirs", (Bangladesh, Dhaka: The University Press Ltd., First Published, 2012), PP. XIX-XXII

[12] Islam, Seyed Amirul. "Op.Cit", Pp.14-17 
[13] Rahim, Dr. Muhammad Abdur and Others, "Bangladesher Itihas", (Bangladesh, Dhaka: 2002), P.28

[14]

Bhogel, J.P.H., "Prakrita Inscription from a Buddhist Site at Nagarajunakunda", Epigraphia Indica, Volume-20, India, Calcutta, 1929, PP.22-37

Roy, Niharranjan, "Bangalir Itihas-Aadi Parba", (India, Kolkata: Dey's Publication, 6 edition, Maagh, 1414, BY), PP. 30-35

Ali, Muhammad Mohar, "A History of the Muslims of Bengal, Volume-1/A",

(Bangladesh, Dhaka: Islamic Foundation Bangladesh, Second edition, August 2003, AD), P.5

Rahman, Md. Shahidur, "Aadi Banglar Itihas, Volume-1”, (Bangladesh, Dhaka: IHN, June, 2012), P.60

Ali, Muhammad Mohar, “Op.Cit.”, p.5

Bandapadhya, Rakhaldas, "Banglar Itihas-Protham Bhag”, (Dhaka: Boipatra, February, 2013), p.11

Peterson, Daniel C., "Allah, “, Encyclopedia of Islam and the Muslims World, Vol1, A-L, Vol-2, M-Z, Index, Macmillan Reference in USA, 2004, P.40

Ibid. P.39

Ibid.

Hitti, Philip Khuri, "History of the Arabs: From the Earliest to the Present", (London:Macmillan Education Ltd. Tenth Edition, Twelfth Reprint 1989), pp. 100-1001

Ibid.

Farid, Malik Ghulam, "Dictionary of the Holy Qur'an: With References and Explanation of the Text", (Islamabad: Islam International Publications Limited, First Published in UK in 2006), p.28 Ibid.

'Omar, Abdul Mannan, "Dictionary of the Holy Qur'an: Arabic Words-English Meanings", (Hockessin: Noor Foundation International Inc. Reprint, February, 26, 2010), p.28

The Holy and the Glorious Qur'an, the Surah Name: Al-Ikhlas, The Sura No: 112, The Verse No.1-4

Hossain, Md. Kohinoor, "Sense \& Sensibility on the Designated Muslim Made Theory of Religion", International Journal of Innovative Research \& Development, Volume-2, Issue-1, January, 2013, India, Kolkata, ISSN: 2278-0211, PP.692-693 The Holy and the Glorious Qur'an, the Surah Name: Al-Bakarah, The Sura No: 2 , The Verse No.256

The Holy and the Glorious Qur'an, the Surah Name: Ar-Rum, The Sura No: 30, The Verse No.22

Mussolini, "Muslims Killed 600 Millions Hindus! ”, http//www.danielpipe.org /mment-172982, that is submitted by him: India, May 18, 2010

Ahmed, Anis, "Bangladesh 1971: War Crimes, Genocide and Crimes against Humanity Operation Search Light: The Targets", www.google.com

Anisuzzaman, "Creativity, Reality and Identity", (Bangladesh, Dhaka: I.C.B.S., 1993), P.107

The Daily Dawn, February 19, 1949, and March 21, 1951

Government of Bangladesh, "Parliamentary Debates, October, 12, 1972",

(Bangladesh, Dacca: Government of Bangladesh, 1972), P.20

"The Constitution of the People's Republic of Bangladesh", Ministry of Law, (Bangladesh, Dacca: Government of Bangladesh, 1972), P.5

Maniruzzaman, Talukdar, "Bangladesh Politics: Secular and Islamic Trends, Religion, Nationalism and Politics in Bangladesh", (India, New Delhi: SAB, 1990), P.69

"Ghoshonapatra", Bangladesh, Dacca: BNP, 1978

"The Constitution of Bangladesh", (Bangladesh, Dhaka: The Government of Bangladesh, 1991), P.9

Ghosh, Partho, "Cooperation and Conflict in South Asia", (Bangladesh, Dhaka: 
The University Press Ltd., 1989), P.71

[42] The Daily Star, Bangladesh, Dhaka, February $4^{\text {th }}, 2008$

[43] Bhardwaj, Dr. Sanjoy Kumar, "Contesting Identities in Bangladesh: A Study of Secular and Religious Frontiers", Asia Research Centre, LSE, Ratan Tata Fellow 2009-2010, India, Working Paper-36

[44] United Nations: General Assembly, A/HRC/31/18/Add.2, Distr.: General, 22

January, 2016, P.6

[45] Ibid. P.5

[46] Ibid. P.10

[47] Ibid. P.12

[48] Rahman, Mahbubur, “Op.Cit.”, Pp. 11-112

[49] Wise, James M.D. (Trans.) Karim Faujul, "Purbabanger Bibhinno Jati, Barno, O Pesher Bibaran", (Bangladesh, Dhaka: ICBS, University of Dhaka, $3^{\text {rd }}$ Printing, April, 2000), P.24

[50] Jabbar, Md. Abdul, “Bangladesher Itihas-(Prachin Jug)”, (Bangladesh, Dhaka: Sikder Prokashoni, $1^{\text {st }}$ Edition, September, 2007)

[51] The Holy and the Glorious Qur'an, the Sura Name: Al-Araf, The Sura No: 7, The Verses No: 19-27

[52] The Holy and the Glorious Qur'an, the Sura Name: Luqman, The Sura No: 31, The Verse No: 14

[53] The Holy and the Glorious Qur'an, the Sura Name: Al-Ahqaf, The Sura No: 46, The Verse No: 15

[54] The Holy and the Glorious Qur'an, the Name: Al-Nahl, The Sura No: 16, The Verses No: 58-59

[55] The Holy and the Glorious Qur'an, the Sura Name: Al-Hujrat, The Sura No: 49, The Verse No: 13

\section{Copyrights}

Copyright for this article is retained by the author(s), with first publication rights granted to the journal. This is an open-access article distributed under the terms and conditions of the Creative Commons Attribution License (http://creativecommons.org/licenses/by/4.0/). 